\title{
Anthrax in South Africa: Economics, Experiment and the Mass Vaccination of Animals, c. 1910-1945
}

\author{
DANIEL GILFOYLE*
}

\section{Introduction}

During 1923, the South African government began to issue free vaccine for the immunization of cattle against anthrax. Five years later, it introduced compulsory annual vaccination in parts of the Transkeian Territories, an area reserved for occupation by Africans. Thereafter, the state sought to extend both compulsory and discretionary vaccination. In 1942, scientists at the government's Onderstepoort Veterinary Institute announced that they had issued 6 million doses of vaccine during the previous year. Approximately half the cattle in the country were being immunized annually with a special product which scientists at the Institute had recently devised. ${ }^{1}$ The scale of vaccination was unprecedented within the country and the annual issue of anthrax vaccine far surpassed the amount supplied for any other animal disease. It was a major state intervention in rural society. Nevertheless, vaccination against anthrax in South Africa is absent from the historiography, while published contemporary accounts are few. ${ }^{2}$

The history of anthrax control in South Africa, which concerns public policy and technical innovation, relates to the wider historiography of medicine, science and technology in the British Empire. If Daniel Headrick has interpreted various innovations in science and medicine as "tools of empire", which enabled colonists to conquer indigenous populations and overcome hostile environmental conditions, ${ }^{3}$ historians have more recently been concerned with the ways in which western medicine assisted colonial administrations in extending social control over the colonized. ${ }^{4}$ Medical science underpinned militaristic public health policies and sanitary measures, in which vaccination,

(C) Daniel Gilfoyle 2006

* Daniel Gilfoyle, DPhil, Wellcome Unit for the History of Medicine, 45-47 Banbury Road, Oxford OX2 6PE, UK.

I would like to thank the Wellcome Trust for a grant which made researching this article possible.

\footnotetext{
${ }^{1}$ M Sterne, J Nicol and M C Lambrechts, 'The effects of large-scale active immunization against anthrax', Journal of the South African Veterinary Medical Association (JSAVMA), 1942, 13: 53-63, pp. 53-4.

$2 \mathrm{~J}$ Nicol, 'Anthrax control in native reserves', JSAVMA, 1933, 4: 46-7.

${ }^{3} \mathrm{D}$ R Headrick, The tools of empire: technology and European imperialism in the nineteenth century, Oxford University Press, 1981; idem, The tentacles of
}

progress: technology transfer in the age of imperialism, 1850-1940, Oxford University Press, 1988.

${ }^{4}$ Important texts are D Arnold (ed.), Imperial medicine and indigenous societies, Manchester University Press, 1988; R MacLeod and M Lewis (eds), Disease, medicine and empire: perspectives on western medicine and the experience of European expansion, London and New York, Routledge, 1988; M Vaughan, Curing their ills: colonial power and African illness, Stanford University Press, 1991; D Arnold, Colonising the body: state medicine and epidemic disease in nineteenth-century India, Berkeley and London, University of California Press, 1993; M Harrison, Public health in British India: Anglo-Indian preventive medicine, 1859-1914, Cambridge University Press, 1994; A Cunningham and B Andrews (eds), Western medicine as contested knowledge, Manchester University Press, 1997. 


\section{Daniel Gilfoyle}

particularly against smallpox, at times played a significant part. ${ }^{5}$ In Africa, such interventions sometimes disrupted long-established methods of disease control based on environmental regulation, with disastrous results for the health of the colonized. ${ }^{6}$

In South Africa too, historians have been concerned with the relation of racially biased medical institutions, public policies and private practice to the imposition and development of segregation and apartheid. ${ }^{7}$ In this regard, however, Harriet Deacon has suggested a contradiction between the analysis of western medicine as a means by which the state extended control over Africans and the argument that Africans have suffered because they have been excluded from the benefits to health that it has potentially offered. ${ }^{8}$

A similar contradiction is evident in the rather scant historiography of state veterinary services and science in South Africa (and elsewhere in the continent). ${ }^{9}$ While more detailed accounts of veterinary scientists and their activities have begun to emerge, ${ }^{10}$ veterinary science has been interpreted generally as a means of enabling white "settler" stock farmers to overcome problems of production posed by disease and environment, or even as an indirect subsidy to enable them to overcome competition from African producers. ${ }^{11}$ Historians have also focused on political conflict associated with state interventions aimed at controlling rinderpest and East Coast fever among African-owned cattle, arguing that these epizootics were occasions on which the state sought to extend political and social control over

\footnotetext{
${ }^{5} \mathrm{D}$ Arnold, 'Smallpox and colonial medicine in nineteenth-century India', in Arnold (ed.), Imperial medicine, op. cit., note 4 above, pp. 45-65.

${ }^{6}$ In this regard, trypanosomosis has been a major focus. See, for example, J Ford, The role of trypanosomiases in African ecology: a study of the tsetse fly problem, Oxford, Clarendon Press, 1971; H Kjekshus, Ecology control and economic development in East African history: the case of Tanganyika, 1850 1950, London, Heinemann Educational, 1977; M Lyons, The colonial disease: a social history of sleeping sickness in northern Zaire, 1900-1940, Cambridge University Press, 1992; K Arden Hoppe, Lords of the fly: sleeping sickness control in British East Africa, 1900-1960, Westport, CT, Praeger, 2003.

${ }^{7}$ See, for example, S Marks, Divided sisterhood: class, race, and gender in the nursing profession in South Africa, London, Macmillan, 1994; S Marks and $\mathrm{N}$ Andersson, 'Issues in the political economy of health in Southern Africa,' J. Southern Afr. Stud., 1987, 13 (2): 177-86; R Packard, White plague, black labour: tuberculosis and the political economy of health and disease in South Africa, Pietermaritzburg, University of Natal Press and James Currey, 1989; M Swanson, "The sanitation syndrome": bubonic plague and urban native policy in the Cape Colony, 1900-1909', J.Afr. Hist., 1977, 18 (3): pp. 387-410; M Swanson, 'The Asiatic menace: creating segregation in Durban 1870-1910', International Journal of African Historical Studies, 1983, 16 (3): 401-21; E B van Heyningen, 'Agents of empire: the medical profession in the Cape Colony, 1880-1910', Med. Hist., 1989, 33: 450-71.
}

${ }^{8}$ H Deacon, 'Racism and medical science in South Africa's Cape Colony in the mid- to late nineteenth century,' Osiris, 2000, 15: 190-206, p. 191.

${ }^{9}$ Critical accounts of veterinary medicine in Africa are few. See, however, J L Giblin, 'East Coast fever in socio-historical context: a case study from Tanzania', International Journal of African Historical Studies, 1990, 23 (3): 401-21; R Waller and K Homewood, 'Elders and experts: contesting veterinary knowledge in a pastoral community', in Cunningham and Andrews (eds), op. cit., note 4 above, pp. 69-93.

${ }^{10} \mathrm{~W}$ Beinart, 'Vets, viruses and environmentalism at the Cape', Paideuma, 1997, 43: 227-52; D Gilfoyle, 'Veterinary science and public policy at the Cape, c. 1877-1910', DPhil Thesis, University of Oxford, 2002.

${ }^{11} \mathrm{~J}$ Krikler, Revolution from above, rebellion from below: the agrarian Transvaal at the turn of the century, Oxford, Clarendon Press, 1993, pp. 77, 80-3; S Milton, 'To make the crooked straight: settler colonialism, imperial decline and the South African beef industry, 1902-1942', $\mathrm{PhD}$ thesis, University of London, 1996, pp. 34-6. Milton also identifies a brief period during the mid-1940s when the state adopted a more positive attitude towards cattle production by Africans. S Milton, 'The Transvaal beef frontier: environment, markets and the ideology of development, 1902-1942', in T Griffiths and L Robin (eds), Ecology and empire: environmental history of settler societies, Edinburgh, Keele University Press, 1997, pp. 199-212, on pp. 208-9. 


\section{Anthrax in South Africa, c. 1910-1945}

Africans. ${ }^{12}$ The extension of veterinary services to African-owned stock through vaccination against anthrax is, however, incongruent with these interpretations of state policy. While it may be argued that state attempts to control anthrax in African areas were intended to benefit white stock farming by tackling possible sources of infection, the idea that state veterinary services operated simply for its benefit needs to be qualified. The motivation for the extension of state veterinary services to African areas, and the way it functioned in practice, requires further analysis. I argue that mass vaccination in African areas, made possible by the operation of bureaucratic regulatory systems and asymmetrical power relations in a racially segregated society, was an important means by which state-employed veterinary scientists acquired knowledge about the disease and evaluated innovations in vaccine technology.

During the 1920s, officials in the Department of Agriculture became increasingly concerned about the threat of restrictions upon pastoral exports from South Africa because of their contamination with anthrax. In response, government vets promoted and later enforced vaccination against the disease, but for various reasons the practice was unsatisfactory as a method of prevention and control. This led to a period of experiment during which South African veterinary scientists sought to develop improved vaccines through technological innovation. The compulsory vaccination of African-owned cattle provided a means of obtaining a statistical basis for the evaluation of these new methods and products. ${ }^{13}$ Laboratory investigations and field vaccination, with associated state-enforced regulations, were thus components of an experimental system in which the results obtained by vets in the field informed both technological adjustment and social policy. ${ }^{14}$ Vaccination against anthrax in African-occupied areas such as the Transkei, carried out under the control of state officials, was a means of testing a technology which was eventually used throughout South Africa and more widely around the world. I examine experimental method in the investigation of anthrax and the development of the vaccine in some detail. This article is therefore intended to contribute to the historiography of scientific practice in bacteriology and immunology during the 1920s and 1930s. ${ }^{15}$

\footnotetext{
${ }^{12} \mathrm{~W}$ Beinart, 'The anatomy of a rural scare: East Griqualand in the 1890s', in W Beinart and C Bundy, Hidden struggles in rural South Africa: politics and popular movements in the Transkei and Eastern Cape 1890-1930, London, James Currey; Johannesburg, Ravan Press, 1987, pp. 46-77; C Bundy, “"We don't want your rain, we won't dip": popular opposition, collaboration and social control in the anti-dipping movement, 1908-1916', in ibid., pp. 191-221; P Phoofolo, 'Epidemics and revolutions: the rinderpest epidemic in late nineteenth-century South Africa', Past and Present, 1993, 138: 112-43; C van Onselen, 'Reactions to rinderpest in southern Africa, 18961897', J. Afr. Hist., 1972, 13: 473-88.

${ }^{13}$ On the increasing importance of statistical methods for clinical trials during the twentieth century, see J R Matthews, Quantification and the quest for medical certainty, Princeton University Press, 1995. For a more general overview of the role of quantitative methods in dealing with uncertainty in problems of government, see I Hacking, 'How should we do the
}

history of statistics', in G Burchell, C Gordon, and P Miller (eds), The Foucault effect: studies in governmentality with two lectures by and an interview with Michel Foucault, London, Harvester Wheatsheaf, 1991, pp. 181-96.

${ }^{14}$ A M Silverstein, 'The heuristic value of experimental systems', J. Hist. Biol., 1994, 27: 437-47.

${ }^{15}$ While much has been written on bacteriology, "germ theory" and the "laboratory revolution" in medical science between 1870 and 1910, coverage for the later period is much thinner. Some important texts for the earlier period are T D Brock, Robert Koch: a life in medicine and bacteriology, Madison, Science Tech Publishers, 1988; A Cunningham and P Williams (eds), The laboratory revolution in medicine, Cambridge University Press, 1992; G L Geison, The private science of Louis Pasteur, Princeton University Press, 1995; M Worboys, Spreading germs: disease theories and medical practice in Britain, 1865-1900, Cambridge University Press, 2000. The major works on the history of immunology in the twentieth century 


\section{Daniel Gilfoyle}

The first part provides context by describing the establishment and growth of state veterinary institutions and services as a response to problems of disease. In the second part, I describe how officials became increasingly concerned with the prevention and control of anthrax during the early 1920s, particularly in the context of international attempts to protect workers in the textile industry from the danger of contaminated wool and hair. In the third part, I examine veterinary ideas about the nature of anthrax in South Africa and attempts at control up to the 1930s, showing how the compulsory mass vaccination of African-owned cattle became an important component of state policy. Government veterinary scientists, however, emphasized various perceived peculiarities of anthrax in the region and argued that these limited the value of imported technological systems during a period when the practice of vaccination greatly expanded. The final section analyses laboratory experiments and technical innovations, the use of statistical studies obtained through compulsory mass vaccination and the further extension of the practice.

\section{The Animal Economy and Veterinary Institutions}

Domestic animals provided an important source of food and traction for the indigenous peoples of southern Africa and the early Dutch colonists at the Cape. From the 1820s, when the British government actively encouraged immigration to the Cape of Good Hope, pastoral production became increasingly commercialized. The new colonists imported wool-producing merino sheep, which thrived in the semi-arid Karoo and in parts of the Eastern Cape. As production increased rapidly through the mid-nineteenth century, wool became the Cape's major export, its sale on the British markets drawing the colony into the international economy. Later, wool exports were substantially supplemented by the production of mohair from angora goats, another settler import. While the expansion of diamond mining from the 1870s, and gold mining from the 1890s, transformed southern African societies, the exploitation of minerals did not displace pastoralism as a pillar of South Africa's economy until after the mid-twentieth century. ${ }^{16}$ Furthermore, the urbanization which followed the large-scale exploitation of minerals created markets for meat and dairy products, further stimulating the growth of commercial pastoralism. During the late nineteenth century, parts of the Eastern Cape became important centres for cattle farming and dairying, while colonial pastoralists sought to develop ranch-style beef production on the grasslands of the Northern Cape and, from the early twentieth century, in the adjoining parts of the Western Transvaal. ${ }^{17}$ White commercial pastoral farming was therefore a major concern of the South African government throughout the period under review.

are theoretically oriented and concern debates and controversies between scientists in leading institutions. See P M H Mazumdar, Species and specificity: an interpretation of the history of immunology, Cambridge University Press, 1995; A M Silverstein, A history of immunology, San Diego, Academic Press, 1989. Some recent contributions to the history of experimental practice in immunology are W Anderson, 'Immunities of empire: race, disease, and the new tropical medicine, 1900-1920', Bull. Hist. Med., 1996, 70: 94-118; P M H Mazumdar, “"In the silence of the laboratory": the League of Nations standardizes syphilis tests', Soc. Hist. Med., 2003, 16: 437-59; and K Waddington, 'To stamp out "so terrible a malady": bovine tuberculosis and tuberculin testing in Britain, 1890-1939', Med. Hist., 2004, 48: 29-48.

${ }^{16} \mathrm{~W}$ Beinart, The rise of conservation in South Africa: settlers, livestock and the environment 1770-1950, Oxford University Press, 2003, especially pp. $9-17$.

${ }^{17} \mathrm{~K}$ Shillington, 'Irrigation, agriculture and the state: the Harts Valley in historical perspective', in 


\section{Anthrax in South Africa, c. 1910-1945}

The expansion of commercial pastoralism, however, was neither continuous nor without problems. From the 1870s, colonist farmers, particularly in the wetter, eastern parts of the Cape and in Natal, became increasingly convinced that stock diseases presented serious obstacles to the expansion of animal numbers. The population of sheep and angora goats in some of the Eastern Cape districts began to decline very rapidly during the 1870 s and the concerns of farmers resulted in the appointment of the first government veterinary surgeon in the Cape during 1876, following a similar appointment in Natal. Farmers who gave evidence to the Cape's Stock Diseases Commission of 1877 described how mysterious diseases had destroyed many flocks. The early government vets sought to investigate these diseases, but the small number of appointments, together with a heavy administrative burden, meant that they made little progress in this direction until the end of the nineteenth century. ${ }^{18}$

The African rinderpest epidemic, which reached southern Africa in 1896 and threatened to devastate cattle holdings, was a major impetus to the expansion of veterinary services. Thereafter, additional professional appointments at the Cape enabled state-employed veterinary scientists to engage in more systematic research. ${ }^{19}$ Following British victory over the Afrikaner republics of the Transvaal and Orange Free State in the South African War (1899-1901), Lord Alfred Milner supervised the reconstruction of the defeated states, with the objective of a unified South Africa. ${ }^{20}$ Milner, a prime exponent of constructive imperialism, was committed to harnessing science to the development of "settler" commercial agriculture, a policy which was accompanied by the exclusion of African peasant producers. He set up a modernizing Department of Agriculture, including the Swiss-trained veterinary scientist Arnold Theiler to undertake research. ${ }^{21}$ A British vet, Stewart Stockman, was appointed to lead a veterinary department consisting largely of British-trained practitioners, the major function of which was the control of infectious and contagious diseases in the field. ${ }^{22}$

In 1902, the highly virulent tick-borne disease of cattle, East Coast fever, broke out in the Transvaal. Over the next ten years, it spread throughout the Transvaal lowveld, Natal, the Transkei and into the Eastern Cape, where the environmental conditions supported the tick vector. East Coast fever, which produced morbidity and mortality rates above 90 per cent, threatened to destroy the cattle industry of South Africa and made state veterinary services indispensable. It provoked a vigorous, if sometimes politically controversial response from the Transvaal's new veterinary department, which was based on an extensive regulatory system consisting of the dipping of cattle against ticks, movement embargoes, quarantines and sometimes the destruction of the infected herd. East Coast fever remained a major

W Beinart, P Delius, and S Trapido (eds), Putting a plough to the ground: accumulation and dispossession in rural South Africa, 1850-1930, Johannesburg, Ravan Press, 1986, pp. 311-35; Milton, 'To make the crooked straight', op. cit., note 11 above, p. 119.

${ }^{18}$ Beinart, op. cit., note 10 above; Gilfoyle, op. cit., note 10 above.

${ }^{19}$ D Gilfoyle, 'Veterinary research and the African rinderpest epizootic: the Cape Colony, 1896-1898', J. Southern Afr. Stud., 2003, 29 (1): 133-54.

\footnotetext{
${ }^{20} \mathrm{~S}$ Marks and S Trapido, 'Lord Milner and the South African state', History Workshop, 1979, 8: 51-80.

${ }^{21}$ Arnold Theiler was born in Frick, Switzerland and studied to be a veterinarian at Bern and Zurich. He emigrated to the South African Republic in 1893, but failed to obtain state employment as a vet until the rinderpest epizootic of 1896. For a biography, see T Gutsche, There was a man, Cape Town, Howard Timmins, 1976.

${ }^{22}$ Krikler, op. cit., note 11 above, pp. 80-3.
} 


\section{Daniel Gilfoyle}

preoccupation of the veterinary department until it was finally eradicated from South Africa during the 1950 s. $^{23}$

Throughout the 1900s, Arnold Theiler conducted research into various aspects of East Coast fever, which provided the knowledge base for control measures. He was rewarded, in 1908, with modern laboratory facilities at Onderstepoort, about ten miles north of Pretoria. Following the establishment of the Union of South Africa in 1910, the Onderstepoort Veterinary Bacteriological Laboratories, later the Onderstepoort Veterinary Institute, became the centre for veterinary research throughout South Africa. Theiler oversaw the inauguration of a veterinary faculty as part of the University of Pretoria in 1920, which awarded degrees and doctorates in veterinary medicine. Thus began a period during which the veterinary profession was increasingly "South Africanized" and the pursuit of research became less dependent on imported expertise. By the 1930s, veterinary appointees were typically white, male South Africans, frequently the sons of farmers. Theiler retired in 1927 and a new director, Petrus Johann du Toit, an Afrikaner, was appointed as his replacement. Du Toit's appointment was accompanied by a significant bureaucratic reorganization, as the veterinary field services were now formally brought under Onderstepoort's control. Du Toit thus took charge of the overall formulation of veterinary policy and field activities, as well as research. ${ }^{24}$

As East Coast fever was gradually controlled during the 1910s, the research agenda at Onderstepoort diversified. Given the increasingly segregationist nature of South African society, the overall direction of research was determined largely by the concerns of white farmers. A series of groundbreaking studies in plant toxicology, botulism in animals and nutrition, which were of wider relevance to pastoralism throughout the world than the early work on "tropical animal diseases", such as East Coast fever, brought the Institute to international prominence during the 1920s. Immunological studies, many of which adapted technological innovations made in metropolitan countries, were an important component of research during the 1930s. Veterinary scientists working at Onderstepoort released vaccines against the insect-borne viral diseases African horsesickness and bluetongue (sheep) and against anthrax. These vaccines and associated technologies were exported to other parts of the British Empire and beyond, further bolstering the reputation of the

\footnotetext{
${ }^{23}$ P F Cranefield, Science and empire: East Coast fever in Rhodesia and the Transvaal, Cambridge University Press, 1991.

${ }^{24} \mathrm{~K}$ Brown, 'Tropical medicine and animal diseases: Onderstepoort and the development of veterinary science in South Africa, 1908-1950', J. Southern Afr. Stud., 2005, 31 (3): 413-29.

Petrus J du Toit (1888-1967) was born at Somerset Strand in the Western Cape. He studied zoology at Victoria College (later the University of Stellenbosch) and subsequently in Germany and Switzerland. He was awarded the degrees of DPhil in zoology at the University of Zurich in 1912 and Doctor of Veterinary Medicine at the University of Berlin in 1916. Despite holding a British passport, he worked during the First World War at the Veterinary Hochschule, publishing
}

a major textbook on tropical diseases of domestic animals in collaboration with Professor Paul Knuth in 1921. He returned to South Africa to take up a post at Onderstepoort in 1919 and succeeded Arnold Theiler as Director in 1928, a post which he held until his retirement in 1948. While directing research at Onderstepoort, teaching at the Veterinary Faculty of the University of Pretoria and participating in international science organizations, du Toit published many important contributions in the fields of tropical animal diseases, immunology and nutrition. D G Kingwill and B J F Schonland, 'Petrus Johann du Toit 1888-1967,' Biographical Memoirs of Fellows of the Royal Society, 1969, vol. 15, pp. 247-66. 
Institute abroad and enabling it to take an increasingly prominent part in the "polycentric communications network" of international veterinary science. ${ }^{25}$

\section{Anthrax and the Origins of an Economic Problem}

The origins of anthrax in South Africa are obscure, but by at least the mid-nineteenth century the disease was familiar to Anglophone farmers and Dutch pastoralists, who called it "miltziekte" (spleen sickness) because of the swollen spleen which they found on postmortem examination. The British vets employed as government officials in the Cape Colony and Natal during the 1870 s were also familiar with this fatal disease. The first government vet at the Cape, William Catton Branford, saw cases of anthrax shortly after his appointment in 1876 . He advised farmers not to dismember the carcasses, but to bury them intact with quicklime to prevent the contamination of the pasture with the anthrax organism. $^{26}$

During the 1890 s, the Cape government vets perceived anthrax as an increasingly serious and widespread hazard. Otto Henning, a state-employed vet who worked in the commercial cattle-ranching areas of the Northern Cape and British Bechuanaland (annexed to the Cape in 1895), thought the disease was gaining a significant hold and that some farms had become badly contaminated. Following the British victory in the South African War in 1901, newly-appointed veterinary officials found that contiguous parts of the Western Transvaal, an area which Milner's reconstruction government had prioritized for the development of settler cattle farming, had acquired an "evil reputation" for anthrax among local farmers. ${ }^{27}$ The vets also became increasingly concerned about the prevalence of the disease along the roads between the ports of the Eastern Cape and the Transkei. Both white and African transport riders, the vets claimed, frequently left anthrax carcasses unburied were they had fallen, causing long-term contamination. Some "outspans" on the transport riding routes were allegedly hotbeds of infection. ${ }^{28}$

During the 1910s, government vets became convinced that the large majority of anthrax cases went unreported and that the disease was far more common than the official statistics suggested. ${ }^{29}$ In this regard, the intensified veterinary supervision that followed the imposition of the East Coast fever regulations (which required the submission of blood smears for every cattle death in proclaimed areas) in the Transkei during 1910 enabled officials to gain a clearer insight. The number of cases detected rose dramatically after the imposition of the

\footnotetext{
${ }^{25}$ D Gilfoyle, 'Veterinary immunology as colonial science: method and quantification in the investigation of horsesickness in South Africa, c.1905-1945', J. Hist. Med. Allied Sci., 2006, 61: 26-65. The phrase is taken from D Wade Chambers and R Gillespie, 'Locality in the history of science: colonial science, technoscience and indigenous knowledge', Osiris, 2000, 15: 221-40.

${ }^{26}$ Cape of Good Hope [G.8-1877], Report of the colonial veterinary surgeon on sheep and cattle diseases in the Colony of the Cape of Good Hope, Cape Town, Government Printer, 1877 , p. 20.
}

\footnotetext{
${ }^{27}$ Milton, 'The Tranvaal beef frontier', op. cit., note 11 above, p. 199; A Theiler and C E Gray, 'Veterinary hygienic principles applicable to stock in South Africa', Transvaal Agricultural Journal, 1906, 4: 771-91, p. 783.

${ }^{28}$ Cape of Good Hope [G.41-1904], Reports of the Chief Veterinary Surgeon and the Assistant Veterinary Surgeons for the year 1903, Cape Town, Government Printer, 1904, p. 60.

${ }^{29}$ D Kehoe, 'Anthrax in South Africa', in The fifth and sixth reports of the Director of Veterinary Services, April 1918, Pretoria, Government Printer, 1919, pp. 211-53, esp. p. 215.
} 


\section{Daniel Gilfoyle}

regulations, ${ }^{30}$ and a similar increase followed the proclamation of the Eastern Cape districts of Kingwilliamstown and East London shortly afterwards. ${ }^{31}$ The vets believed that without the regulations most of these outbreaks would have gone undetected, and speculated that closer inspection would reveal a similar picture in other parts of the country. ${ }^{32}$ Nevertheless, the annual number of reported deaths from anthrax remained quite small. During 1920, for example, 1,891 outbreaks of the disease were reported in South Africa, killing just over 6,000 cattle. ${ }^{33}$ While the number of deaths was small as a percentage of the overall population of approximately 6 million cattle, the vets emphasized the potential for the disease to contaminate farms and make them unworkable. Throughout the 1910s they accordingly pressed for the enforcement of measures of control. ${ }^{34}$

The initial motivation for a more thorough policy of control and prevention after 1920, however, lay in the threat anthrax posed to human health abroad. ${ }^{35}$ In Britain and America there was, during the 1910 s, continuing concern about the small but persistent number of cases of anthrax infection among workers handling imported wool and hair. The chief danger was the inhalation of the anthrax organism, which caused the potentially fatal "woolsorters" " disease. During 1916, the United States government promulgated regulations requiring the disinfection of animal products from regions in which anthrax was prevalent. ${ }^{36}$ The American consul immediately refused to certify hides from the Transvaal, effectively closing the American market to South African producers. ${ }^{37}$

\footnotetext{
${ }^{30}$ In 1905 , before the imposition of the East Coast regulation only 16 cases were reported in the Transkei. By 1913, the figure stood at 116, rising to 265 in 1920. Union of South Africa [U.G.47-1913], Report of the Department of Agriculture, $1^{\text {st }}$ January 1912 to $31^{\text {st }}$ March 1913, Pretoria, Government Printing and Stationery Office, 1913, p. 55; Union of South Africa [U.G.13-1921], Annual report of the Department of Agriculture, 1919-1920, Pretoria, Government Printing and Stationery Office, 1921, p. 20. P R Viljoen, H H Curson and P J J Fourie, 'Anthrax in South Africa with reference to improved methods of protective inoculation', in $13^{\text {th }}$ and $14^{\text {th }}$ reports of the Director of Veterinary Education and Research, Part I. October 1928, Pretoria, Government Printing and Stationery Office, 1928, pp. 431-535, on pp. 447-9.

${ }^{31}$ Union of South Africa [U.G.47-1913], Annual report of the Department of Agriculture, $1^{\text {st }}$ January 1912 to $31^{\text {st }}$ March 1913, Pretoria, Government Printing and Stationery Office, 1913, p. 55; Kehoe, op. cit., note 29 above, pp. 215-17; Viljoen, et al., op. cit., note 30 above, pp. 437-8.

${ }^{32}$ Union of South Africa [U.G.47-1913], Report of the Department of Agriculture, $1^{\text {st }}$ January 1912 to $31^{\text {st }}$ March 1913, Pretoria, Government Printing and Stationery Office, 1913, p. 55; Kehoe, op. cit., note 29 above, p. 215; Viljoen, et al., op. cit., note 30 above, pp. 438,454 .

${ }^{33}$ Union of South Africa, [U.G.13-1921], Annual report of the Director of Agriculture, 1919-1920,
}

Pretoria, Government Printing and Stationery Office, 1921, p. 20.

${ }^{34}$ For example, Theiler and Gray, op. cit., note 27 above, p. 784; Union of South Africa [U.G.5-1918], Annual report of the Department of Agriculture, 1916-1917, Pretoria, Government Printing and Stationery Office, 1918, p. 32; Union of South Africa [U.G.39-1918], Annual report of the Department of Agriculture, 1917-1918, Pretoria, Government Printing and Stationery Office, 1918, p. 40; Union of South Africa [U.G.40-1919], Annual report of the Department of Agriculture, 1918-1919, Pretoria, Government Printing and Stationery Office, 1919, p. 36.

${ }^{35}$ A small number of cases of anthrax were reported annually in South Africa, usually in Africans who had handled cattle hides. See correspondence in South African Nation Archives Depot (SABE) ARB 121 CF161/10/2.

36 'Regulations governing the certification and disinfection of hides, fleshings, hide cuttings, parings, and glue stock, sheepskins and goatskins and parts thereof, hair, wool, and other animal by-products, hay, straw, forage, or similar material offered for entry into the United States', Board of Trade Journal, 21 Dec. 1912.

${ }^{37}$ SABE GG 1854 54/509, Consul General, United States of America to the Governor-General of the Union of South Africa, 12 Feb. 1917. 


\section{Anthrax in South Africa, c. 1910-1945}

With regard to Britain, the major export market for South African wool and mohair, the situation was potentially more serious. In 1910, the Anthrax Investigation Board of Bradford detected anthrax in samples of bloodstained South African mohair. ${ }^{38}$ A Departmental Committee on anthrax (appointed in 1914) recommended the construction of a pilot disinfection plant to treat wool and mohair from countries in which contamination was likely. ${ }^{39}$ It also evaluated the prevalence of anthrax and measures for its control in the exporting colonies. The Committee found that the situation in Australia and New Zealand was satisfactory, but the lack of efficient controls in Egypt and India meant that their products would require disinfection. ${ }^{40}$ The position with regard to South Africa was less clear. The Committee found that "the state of civilisation" there was sufficient for anthrax to be "stamped out", but "the desirability of applying disinfection would have to be considered". 41

Given the importance of wool and other pastoral exports to the South African economy, the perceived threat to trade caused some alarm among the South African government. Officials in the Department of Agriculture calculated that should Britain impose compulsory disinfection, the estimated surcharge of around one and a half pence per pound in weight of wool would entail a cost of over $£ 1,000,000$ per annum to producers. ${ }^{42}$ Furthermore, they were in danger of being excluded from the group of settler colonies and classified with India and Egypt, a prospect that fitted ill with the government's "progressive" and segregationist ideology. In 1918, a Central Wool Committee, set up under Barney Enslin, the head of the Division of Sheep, was extremely critical of current practices in the wool trade, in which fleeces were stored indiscriminately with bloodstained cattle hides, believed to be the major source of infection. ${ }^{43}$ The Department of Agriculture, anxious to publicize the anthrax problem, issued a press circular emphasizing the threat to producers. ${ }^{44}$ At the same time the Chief Veterinary Surgeon, Charles Gray, warned that, "Unless stock owners bestir themselves and take this disease more seriously, it is more than likely that other countries will place an embargo upon the introduction of

\footnotetext{
${ }^{38}$ SABE GG 1848 54/175, E Blackwell, Home Office to Under Secretary for State, Colonial Office, 16 Dec. 1911.

${ }^{39}$ Great Britain, Departmental Committee on Anthrax, Report of the Departmental Committee appointed to inquire as to precautions for preventing danger of infection from anthrax in the manipulation of wool, goat hair, and camel hair. Volume 1. Report of the Disinfection Sub-committee, Cd. 9057, London, HMSO, 1918. For an account of the disinfection plant at Liverpool, see I Mortimer and J Melling, “ "The contest between commerce and trade, on the one side, and human life on the other": British government policies for the regulation of anthrax infection and the wool textiles industries, 1880-1939', Textile History, 2000, 31: 222-36, pp. 227-32.

${ }^{40}$ Australian wool producers, particularly in New South Wales, had suffered from serious problems with anthrax infection during the late nineteenth and early twentieth centuries. The vaccination of sheep was used extensively as a means of control. J Todd, Colonial
}

technology: science and the transfer of technology in Australia, Cambridge University Press, 1995.

${ }^{41}$ Great Britain, Departmental Committee on Anthrax, Report of the Departmental Committee appointed to inquire as to precautions for preventing danger of infection by manipulation of wool, goat hair, and camel hair. Vol. II. Report of the Committee, Cd. 9057, London HMSO, 1918.

${ }^{42}$ Union of South Africa, Department of Agriculture, Press Circular No. 9/1919, 'Anthrax in wool and mohair', 5 July 1919, p. 4.

${ }^{43}$ Union of South Africa, Department of Agriculture, Report by the Central Wool Committee dealing with the trade in wool, mohair, skins, and hides in South Africa, and recommendations to effect improvements in the present systems, Pretoria, Government Printing and Stationery Office, 1918, pp. 1,3 .

${ }^{44}$ Union of South Africa, Department of Agriculture, Press Circular No. 9/1919, 'Anthrax in wool and mohair', 5 July 1919. 


\section{Daniel Gilfoyle}

animal products from South Africa, which will react detrimentally upon the prosperity of the farmer". 45

At the Colonial Office, Lord Milner, who had supervised the construction of a unified South African state, was apparently anxious that the colony's products should continue to be exempt from disinfection. He sought assurances from the Governor-General that South Africa was doing everything in its power to ensure the prevention and eradication of anthrax. ${ }^{46}$ When the disinfection plant, which was situated in Liverpool, came into operation in July 1921, Egyptian and Indian wool and goat hair were subject to compulsory disinfection, while South African products remained for the time being exempt. ${ }^{47}$ Nevertheless, the problem of the contamination of South African products remained. In November 1922, the Colonial Office warned the Governor-General that investigators had detected the anthrax organism in Cape mohair on eleven occasions between September 1921 and August 1922. ${ }^{48}$

After the First World War, efforts to protect textile workers against infection became internationalized. The International Labour Office set up an Anthrax Commission to investigate the disease around the world. In 1922, the Commission, which was attended by the Cape's Senior Veterinary Officer, Rowland Dixon, ${ }^{49}$ reported that the Liverpool disinfection plant had been successful in reducing the incidence of infection and recommended the establishment of other plants in producing countries where anthrax was prevalent. South African mohair was mentioned specifically as a likely source of infection. ${ }^{50}$ Dixon returned to South Africa urging the need to instigate more effective measures of control. In fact, the threat of compulsory disinfection declined from the mid-1920s, as the British Treasury resisted further expenditure on the Liverpool plant and the International Labour Commission failed to pass a convention requiring universal disinfection of wool and hair, instead concentrating on the threat posed by contaminated cattle hides. ${ }^{51}$ Nevertheless, in 1928 Petrus du Toit, as the newly appointed head of South Africa's veterinary services, warned of the continued vigilance of the health section of the League of Nations. Compulsory disinfection would, he reiterated, impose a substantial cost on South African producers. ${ }^{52}$ If the threat of embargoes faded by the 1930 s, however, officials in South Africa continued to stress the potential of the disease to contaminate pastures, and anthrax remained a major veterinary preoccupation.

\footnotetext{
${ }^{45}$ Union of South Africa [U.G.39-1918], Annual report of Director of Agriculture for 1917-18, Pretoria, Government Printing and Stationery Office, 1918 , p. 40. For press reports in a similar vein, see Cape Times, 9 Aug. 1920, 'Anthrax in Union-Chief Veterinary Surgeon's warning to stock owners'; Cape Argus, 9 Aug. 1920, 'Prevalence of anthrax-a growing menace-Veterinary Officer's warning'; Journal of the Department of Agriculture, 1922, 4: 8; 1922, 5: 394-5.

${ }^{46}$ SABE GG 1855 54/597, Lord Milner, Colonial Office to the Officer Administering the Government of the Union of South Africa, 11 Sept. 1920.

${ }^{47}$ Great Britain, Home Office, Prevention of anthrax amongst industrial workers: memorandum on
}

the disinfecting station established in Great Britain for disinfection of wool and hair, London, HMSO, 1921.

${ }^{48}$ SABE GG $185654 / 655$, Colonial Office to Governor-General, 18 Nov. 1922.

${ }^{49} \mathrm{R}$ W Dixon, 'The anthrax problem', Journal of the Department of Agriculture, 1923, 6: 529-38.

${ }^{50}$ Great Britain, International Anthrax Commission, Memorandum circulated by the British Representative, London, HMSO, 1922, p. 7.

${ }^{51}$ Mortimer and Melling, op. cit., note 39 above, p. 230.

${ }^{52} \mathrm{P}$ J du Toit, 'The veterinary service of the Union of South Africa', JSAVMA, 1928, 1: 9-28, p. 12. 
Anthrax in South Africa, c. 1910-1945

\section{The Veterinary Conception of "South African Anthrax" and Control to the 1930s}

The framing of regulations aimed at the control of anthrax in the late nineteenth and early twentieth centuries depended on contemporary understandings of the causal organism, Bacillus anthracis, which had been extensively investigated by Robert Koch during the late 1870s. ${ }^{53}$ As an infected animal approached death, its blood swarmed with millions of the bacilli in the vegetative (multiplicative) form. Once it died, the conditions necessary for the multiplication of the bacilli failed. At moderate temperatures and in the presence of free oxygen, they transformed into inert, highly resistant spores. As the carcass disintegrated, the spores, which could remain viable for an indeterminate period, were deposited on the pasture. If spores entered the blood-stream of a grazing animal through abrasions in the mouth or alimentary tract, they returned to the vegetative state, setting up fatal disease and repeating the cycle of infection and contamination. Anthrax, however, was not considered a contagious disease which passed directly from an infected to a healthy animal. ${ }^{54}$

The South African Stock Diseases Act of 1911, which consolidated existing legislation in the various colonies relating to anthrax (and other contagious and infectious animal diseases), was drafted to deal with the ability of Bacillus anthracis to contaminate through sporulation. ${ }^{55}$ The regulations required owners to report all suspicious deaths to the police or veterinary officials and to submit a blood smear, taken from a small cut in the ear, for laboratory examination. They expressly forbade the opening or dismemberment of the carcass for meat, as this would lead to sporulation and the contamination of the pasture. Owners were required to cremate the carcass promptly or to bury it deeply with quicklime. If the smear tested positive, owners were required to fence off the immediate area to prevent the infection of other animals. As the incubation period of anthrax was short, vets enforced only a brief quarantine to detect associated cases. ${ }^{56}$

These aspects of the South African regulations were based largely upon the British model, which insisted on the control of anthrax by hygienic measures without recourse to Pasteurian vaccination. ${ }^{57}$ Since the rinderpest (cattle plague) epizootic of the mid-1860s, when this disease had been eradicated through the rigorous application of quarantine, slaughter and import embargoes, British veterinary policy had followed a particular trajectory. Based on what Michael Worboys has called "importation theory", 58 it aimed at the eradication of contagious and infectious diseases through slaughter and the prevention of reinfection through import embargoes. With regard to anthrax, this policy was the outcome of several factors which made eradication through hygienic measures an achievable aim. Anthrax was a relatively rare disease in Britain and the state had sufficient resources to detect cases. Furthermore, given the insular nature of the country, it was possible to prevent

\footnotetext{
${ }^{53}$ Koch's explication of the aetiology of anthrax was the basis of his famous "postulates" for establishing a micro-organism as cause of a disease. C Kodell Carter, 'The Koch-Pasteur dispute in establishing the cause of anthrax', Bull. Hist. Med., 1988, 62 (1): 42-57.

${ }^{54} \mathrm{~J}$ MacFadyean, 'Anthrax', J. Comp. Pathol. Ther., 1901, 14: 52-5.

${ }^{55}$ Union of South Africa, Act No. 14, 1911.
}

\footnotetext{
${ }^{56}$ Kehoe, op. cit., note 29 above, p. 230.

${ }^{57}$ Pasteur's vaccine had been available since the early 1880s. For accounts of the development and demonstration of Pasteurian vaccination, see Geison, op. cit., note 15 above, pp. 151-9; B Latour, The Pasteurization of France, Cambridge, MA, and London, Harvard University Press, 1988.

${ }^{58}$ Worboys, op. cit., note 15 above, pp. 56-60, on p. 59 .
} 


\section{Daniel Gilfoyle}

the importation of infected animals. Thus, the British veterinary authorities relied on hygienic measures and discouraged vaccination, which they believed could occasionally cause infection. $^{59}$

By the early twentieth century, however, British-trained veterinary officials in South Africa were convinced that a policy of relying on hygiene alone would fail to control anthrax, given various local circumstances. In contrast to the British example, vaccination became an important element of public policy from the 1910s. There were several reasons for this, which related to the conditions of cattle production in the region and ideas about the nature of the disease itself. The vets considered that the strict enforcement of the regulations under the local conditions of predominantly extensive pastoralism in both white and African areas was impossible. The power of the state to detect outbreaks was limited by the relative weakness of its administration and policing on the ground. Vets working in the field knew from experience that many stockowners did not report cases if they thought these were likely to go undetected by officials. In this regard, the veterinary discussion of the nature of the anthrax problem assumed a distinctly racist tone. According to one government vet, Andrew Goodall, African stockowners were "in the front rank of all our transmitting agents", ${ }^{60}$ while the senior vet, Philip Viljoen argued that, "There is unfortunately a further complication, namely, the native who, generally speaking, is careless in his farming methods and, above all, does not understand food hygiene", 61

Veterinary officials thought that there were three centres of particularly dense anthrax contamination: the Northern Cape districts, such as Vryburg, which had formerly been part of British Bechuanaland and which had been annexed to the Cape in 1895, the Transkei and the Witwatersrand. ${ }^{62}$ In all three areas, they associated anthrax infection with Africanowned cattle and linked its persistence and spread to African practices. The key problem, the vets argued, was that in cases of anthrax Africans flouted the regulations by removing the saleable hide and cutting up the carcass for meat. The Irish veterinarian Daniel Kehoe, who studied anthrax in South Africa during the 1910s, reported that the disease was common along the Witwatersrand, a relatively urbanized area in which gold mining was the principal economic activity. As urbanization based on mining progressed, the increasing number of Africans living in compounds and locations along the Rand provided a growing market for milk and meat. Kehoe reported that there were many milch cows on unfenced plots around the African townships. When an animal died, he alleged, the owner typically evaded the municipal sanitary charge for disposal of the carcass by allowing "mine natives" to cut it up for meat. This, argued the vets, was an efficient means of disseminating anthrax infection across a comparatively densely populated area. ${ }^{63}$ These hides were a prime means of contaminating wool and mohair intended for export, while the

\footnotetext{
${ }^{59} \mathrm{~J}$ MacFadyean, 'Anthrax', J. Comp. Pathol. Ther., 1894, 7 (4): 325-22, and idem, 'Anthrax', J. Comp. Pathol. Ther., 1898, 11, 1: 51-68.

${ }^{60}$ A Goodall, 'Leba', 'The anthrax problem in Southern Africa: mode of spread of disease and practical suggestions for suppression', thesis submitted for fellowship of the Royal College of Veterinary Surgeons, 1921, p. 8.
}

\footnotetext{
${ }^{61}$ Viljoen, et al., op. cit., note 30 above, p. 450. Viljoen was one of the first Afrikaners to qualify as a vet and later served as Secretary for Agriculture.

${ }^{62}$ Union of South Africa [U.G. 47-1913], Annual report of the Department of Agriculture, $1^{\text {st }}$ January, 1912 to $31^{\text {st }}$ March, 1913, Pretoria, Government Printing and Stationery Office, 1913, p. 55.

${ }^{63}$ Kehoe, op. cit., note 29 above, p. 226.
} 


\section{Anthrax in South Africa, c. 1910-1945}

practice of dismemberment allowed the sporulation and more widespread distribution of the bacilli. ${ }^{64}$ The vets, however, did not think that these practices were necessarily rooted in ignorance. Africans were familiar with the disease and seemingly aware of the dangers. According to the botanist, Andrew Smith (writing in the late nineteenth century), Africans rendered infected meat harmless by boiling it with certain herbs, such as Zanthoxylon capensis, then referred to as wild cardamom. ${ }^{65}$ The vets, however, had apparently little interest in investigating the possible disinfectant properties of these plants, even though they were uncertain whether boiling alone was always an effective means of sterilizing meat. ${ }^{66}$

Thus, while European farmers were not exonerated, veterinary officials tended to cast the problem of anthrax control as one which related particularly to Africans. In the reserves of the Northern Cape and the Transkei, where African stockowners grazed their herds on communal pastures, places where large numbers of cattle collected regularly, such as watering points, could become badly contaminated with anthrax spores. Veterinary policy makers believed that they lacked the resources to impose comprehensive measures of hygiene in African areas. In the words of one vet, the suppression of anthrax in areas occupied primarily or wholly by Africans "presents tremendous difficulties", because of extensive communal pastures. ${ }^{67}$

Furthermore, in South Africa anthrax seemed to display particular characteristics. As in Britain, it appeared to be primarily a disease of cattle rather than sheep (as in France and Australia), although the vets admitted that cases in sheep would be difficult to detect under conditions of extensive farming. ${ }^{68}$ The contamination of fleeces probably resulted from contact with other materials, such as cattle hides, rather than from infection in the sheep. Thus, the vets thought that contamination of wool and mohair was a function of infection among cattle. ${ }^{69}$ The vets found a partial explanation for this in the grazing habits of the different species of domestic animals. On the grasslands of Griqualand West in the Northern Cape, where anthrax was common, cattle grazed the grass closely and were liable to pick up spores from the soil. Infection was more likely if prickly pear was present, because the spiny skins could puncture the mouths of grazing animals, thereby providing a means for spores to enter the bloodstream. ${ }^{70}$ In the Karoo, where the disease was virtually unknown, sheep fed upon the leaves of bushes away from the ground and were therefore less likely to ingest spores. The comparative frequency of infection in cattle was the subject of some speculation. Researchers at Onderstepoort found it difficult to infect cattle even by

${ }^{64}$ Agricultural Journal of the Union of South Africa, 1912, 3 (2), Supplement, p. 2; Union of South Africa [U.G.13-1921], Annual report of the Department of Agriculture, 1919-1920, Pretoria, Government Printing and Stationery Office, 1921, p. 20; Kehoe, op. cit., note 29 above, pp. 213, 225, 227, 235, 238; Viljoen, et al., op. cit., note 30 above, p. 450.

${ }^{65}$ Kehoe, op. cit., note 29 above, p. 225; A Smith of St Cyrus, A contribution of South African materia medica, chiefly from plants in use among the natives, Capetown and Johannesburg, Juta, 1895, pp. 55, 58. Smith lists six plants which were used as disinfectants or antidotes. Smith comments that boiling itself might have been effective in disinfecting meat.

${ }^{66}$ Viljoen, et al., op. cit., note 30 above, p. 433.

${ }^{67}$ Goodall, op. cit., note 60 above, p. 8.

\footnotetext{
${ }^{68}$ For descriptions of anthrax in sheep in France and Australia, see Geison, op. cit., note 15 above, pp. 145-6, Todd, op. cit., note 40 above, pp. 37-8, 66-85. In South Africa, however, one vet estimated that around two-thirds of outbreaks of anthrax in South Africa involved cattle only. Goodall, op. cit., note 60 above, p. 6; Viljoen et al., op. cit., note 30 above, p. 459.

${ }^{69}$ Union of South Africa, Report by the Central Wool Committee, op. cit., note 43 above.

${ }^{70}$ Viljoen, et al., op. cit., note 30 above, pp. 449-50. Pasteur had demonstrated that sheep were more likely be become infected if thistles were mixed with the normal food. Kehoe, op. cit., note 29 above, p. 229.
} 


\section{Daniel Gilfoyle}

injecting very large amounts of virulent material, but infection was quite common in nature. It was possible that strains of extreme virulence existed in South Africa, which caused frequent outbreaks in the relatively resistant bovine. ${ }^{71}$ Thus, the species principally affected was of relatively high unit value, which tended to make vaccination an economically justifiable practice.

Vets in South Africa tended to stress the importance of environmental factors in the transmission and dissemination of anthrax. If British veterinarians regarded Bacillus anthracis as an "obligatory" parasite, propagating only in the living animal, little was known about how the organism behaved in nature. Given the appropriate environmental conditions, the vets speculated, it might be able to multiply outside the body. Watering holes were important locations for the transmission of the bacilli, which were possibly able to proliferate in damp soils, rich with decaying matter. ${ }^{72}$ Climate too seemed to have some bearing, as outbreaks were more common after the commencement of summer rains. ${ }^{73}$ While they agreed that the original source of contamination was the carcass of an infected animal, vets noted a tendency for the disease to spread along watercourses and surmised that flowing water carried spores downstream. ${ }^{74}$ Carrion-eating mammals and birds were highly resistant to anthrax, but they probably disseminated the spores over wide areas by depositing them in their excreta. While outbreaks were usually localized affairs that produced relatively few deaths, anthrax sometimes assumed an epidemic form, particularly among horses. This was especially the case in Griqualand West and the Western Orange Free State, where the horsefly (Hippobosca rufipes) proliferated. Vets believed that this fly could carry Bacillus anthracis rapidly beyond the immediate centre of infection, causing localized epidemics, a theory which had also been advanced in the United States. ${ }^{75}$ Given these observations, it seemed possible that Bacillus anthracis was not entirely dependent on the infected animal for propagation and transmission. The evidence suggested that slaughter and hygiene would not be an entirely effective method of controlling the disease.

These considerations meant that, as in much of Western Europe, Australia and United States, where anthrax was widely disseminated across extensive grasslands, vaccination was an important component of state veterinary strategy to control anthrax in South Africa. Unlike in Britain, veterinary officials actively encouraged the use of Pasteur's vaccine to protect in-contact animals in individual outbreaks. ${ }^{76}$ Vaccine was first imported to the Cape from France in the early 1880s, soon after its initial demonstration, but the amount used remained small until the promulgation of the Stock Diseases Act of 1911, which empowered government vets to enforce the vaccination of in-contacts at the owner's expense. Voluntary vaccination, however, was also increasingly popular among the

\footnotetext{
${ }^{71}$ Viljoen, et al., op. cit., note 30 above, p. 464.

${ }^{72}$ Kehoe, op. cit., note 29 above, p. 218.

${ }^{73}$ Viljoen, et al., op. cit., note 30 above, p. 455.

${ }^{74}$ Kehoe, op. cit., note 29 above, p. 230.

${ }^{75}$ This theory was first advanced by the Cape government vet, Otto Henning in 1892 after attending outbreaks of anthrax in horses around Kimberley. M W Henning, Animal diseases in South Africa,

Johannesburg, Central News Agency, 1948, p. 12.
}

\author{
Abstract, 'Blood-sucking insects as transmitters of \\ anthrax', J. Comp. Pathol. Ther., 1918, 31: 134-6. The \\ horsefly theory was later accepted at Onderstepoort \\ after Bacillus anthracis was isolated from \\ hipposboscid flies. Viljoen, et al., op. cit., note 30 \\ above, p. 452. \\ ${ }^{76}$ SABE LDE 2760 123, Notice to Farmers \\ 4828-10/7/14-3000.
}




\section{Anthrax in South Africa, c. 1910-1945}

stock-owning public, so that the annual issue of anthrax vaccine increased from around 40,000 doses in 1911 to $1,200,000$ in $1920 .^{77}$

Given the perceived threat of the compulsory disinfection of wool exports during the early 1920s, the state, now "prepared to do everything in its power to get the disease under proper control", instigated a more determined policy of prevention based on the availability of sufficient effective vaccine. ${ }^{78}$ While veterinary scientists continued to stress the importance of hygienic measures, they increasingly encouraged vaccination, which expanded accordingly. ${ }^{79}$ Until 1915, Onderstepoort imported vaccine from the Pasteur Institute in Paris, but when the First World War interrupted the supply Theiler instructed Kehoe to initiate local production. During 1922, Theiler pressed for legislation giving Onderstepoort control of the supply of anthrax vaccine. As vaccination was now being carried out on a large scale, he argued, the South African farmer needed protection against unduly expensive and possibly defective imported products, which might introduce other infections. It was equally important to prevent the marketing of potentially dangerous vaccines by local amateurs. ${ }^{80}$ Regulations promulgated in 1923 empowered Onderstepoort to forbid the importation of any vaccine from abroad and to suppress local manufacture, a policy that was carried out vigorously. ${ }^{81}$ In effect, Onderstepoort obtained a monopoly of the supply of anthrax vaccine within the country.

If vets could oblige stockowners to vaccinate in-contact animals during any outbreak, by the early 1920 s they believed that the cost of the vaccine tended to discourage farmers from reporting. ${ }^{82}$ To overcome this problem, the government began, from July 1923, to issue free vaccine to stockowners upon request. ${ }^{83}$ Thereafter the use of the vaccine increased rapidly, so that by 1925 Onderstepoort was issuing approximately 2.5 million doses annually. ${ }^{84}$ From the point of view of the veterinary field service, the issue of free vaccine considerably aided control by encouraging notification as required by the Act. The policy continued until 1936, by which time the vets believed that farmers were misusing or wasting large amounts and reintroduced a charge. ${ }^{85}$ Vaccine was still substantially subsidized, however, as the levy of two shillings and sixpence per hundred doses was a quarter of the estimated cost of production. After 1936, the Department of Native Affairs paid for the vaccination of African-owned stock, except in the Transkei, where it was funded out of the existing cattle-dipping tax. ${ }^{86}$ Policy towards the racial groups, however, was different,

\footnotetext{
${ }^{77} \mathrm{P}$ R Viljoen and H H Curson, 'A preliminary communication regarding anthrax spore vaccine and its use in South Africa', South African Journal of Science, 1926, 23: 551-5, p. 555.

${ }^{78}$ Viljoen, et al., op. cit., note 30 above, p. 432.

${ }^{79}$ See, for example, Theiler and Gray, op. cit., note 27 above, p. 785; Kehoe, op. cit., note 29 above, p. 231; Goodall, op. cit., note 60 above, p. 13; Viljoen, et al., op. cit., note 30 above, pp. 450, 472-7; J I Quin, 'Studies on anthrax immunity', Annual report of the Director of Veterinary Services, Onderstepoort, $15^{\text {th }}$ report, Pretoria, volume 1, October, 1929, Pretoria, Government Printer, 1929, pp. 129-82, p. 129; M Sterne and E M Robinson, 'The preparation of anthrax spore vaccine (for cattle and sheep in South Africa)', Onderstepoort Journal of Veterinary Science and Animal Industry (OJVSAI), 1939, 12: 9-21, p. 9.
}

${ }^{80}$ AOVI $1 / 1 / 3$, A Theiler to Secretary for Agriculture, 17 Nov. 1922.

${ }^{81}$ Union of South Africa, Regulation no. 1256, 28 July 1923; SABE LDB 4863 Z10027/16 vol. 2, Secretary for Agriculture to M L Rouhier, Manufacturer's Agent, 9 May 1931.

${ }^{82}$ Viljoen, et al., op. cit., note 30 above, p. 476.

${ }^{83}$ Journal of the Department of Agriculture, 1932, 7 (2): 97

${ }^{84}$ Viljoen, et al., op. cit., note 30 above, p. 432

${ }^{85}$ SABE LDB 4863 Z1002/16 vol. 2, Acting Director of Veterinary Services and Animal Industry to Secretary for Agriculture, Oct. 1930.

${ }^{86}$ SABE LDB 4863 Z1002/16 vol. 1, Direkteur van Veeartsenydiens to Die Senior Veearts, 28 July 1936; SABE LDB 4863 Z1002/16 vol. 2, Director of 


\section{Daniel Gilfoyle}

as vaccination of African-owned livestock was more tightly controlled, with government vets or stock inspectors performing the operation rather than the owners themselves. ${ }^{87}$

Furthermore, senior vets argued that, given the inadequacies of detection, the best method of control and prevention was the compulsory annual vaccination of all cattle in areas considered severely or extensively infected. ${ }^{88}$ During the 1920 s and 1930s, however, the state enforced compulsory vaccination in African areas only. This was determined by the vets' racially biased explanation of the incidence of anthrax and by asymmetric relations of political power between the state, its European constituency and disenfranchized Africans in a segregationist society. Compulsory vaccination was initially enforced across individual African locations during the 1920s at the behest of European farmers in Northern Cape districts such as Barkly West. Here African locations holding large numbers of cattle lay in close proximity to white commercial ranches. ${ }^{89}$

If local European concerns about disease "reservoirs" lay behind this piecemeal vaccination, a more systematic and overarching policy of "block" vaccination began to emerge in the late 1920s, particularly with regard to the Transkeian Territories. The execution of compulsory "block" vaccination was associated with John Nicol, a Britishtrained vet appointed, in 1928, Chief Veterinary Officer for the Transkei by Petrus du Toit, who was now in charge of field services. Since joining the Cape Veterinary Department in 1910, Nicol had accrued much experience of working among Africans and their stock in the Eastern Cape and the Transkei, where his major task had been the enforcement of the East Coast fever regulations. In August 1928, after consulting with the resident magistrate (the head administrative officer), Nicol began the inoculation of all the cattle in Engcobo, a district in the western Transkei which usually accounted for a quarter of the total number of cases detected in the Territories. ${ }^{90}$ Vaccination seems to have been politically uncontroversial and it was rarely mentioned in the discussions of the Transkei's governing body, the General Council. Comment was favourable, apart from some discussion on how the costs should be allocated. ${ }^{91}$ Some Transkeian stockowners were already using free vaccine on a voluntary basis and there were the precedents of earlier inoculations against rinderpest and "lungsickness" (contagious bovine pleuropneumonia). ${ }^{92}$

The anthrax situation in the Transkei came to be of special interest to the vets because they believed that the operation of the East Coast fever regulations gave them a particularly

Veterinary Services to Secretary for Agriculture, 2 July 1938.

${ }^{87}$ SABE LDB 4863 Z1002/16 vol. 2, Senior Veterinary Surgeon, Natal to Director of Veterinary Services, 31 Jan. 1924

${ }^{88}$ Union of South Africa [U.G.40-1919], Annual report of the Director of Agriculture, 1918-1919, Pretoria, Government Printing and Stationery Office, 1919, p. 37.

${ }^{89}$ SABE BAO 5826 2/316 vol. 2, Native Commissioner, Taung, Bechuanaland, to Government Veterinary Officer, Vryburg, 16 Jan. 1930; Native Commissioner, Taung, to Secretary for Native Affairs, Cape Town, 29 March 1930; Superintendent of Natives, Barkly West, to Magistrate, Barkly West, 29 Oct. 1930;
Secretary for Native Affairs to Native Commissioner, Nov. 1930

${ }^{90} \mathrm{Nicol}$, op. cit., note 2 above, p. 46.

${ }^{91}$ Transkeian Territories General Council, Proceedings and reports of the select committees at the session of 1932, annual reports and accounts for 1931 and estimates of revenue and expenditure for 1932-1933, Umtata, 1936, p. 199.

${ }^{92}$ In 1918, the Chief Veterinary Surgeon reported that over 41,000 cattle had been inoculated in the Transkei during the previous year. Union of South Africa [U.G.39-1918], Annual report of the Director of Agriculture, 1917-1918, Pretoria, Government Printing and Stationery Office, 1918, p. 40; Nicol, op. cit., note 2 above, p. 46; Gilfoyle, op. cit., note 19 above; Gilfoyle, op. cit., note 10 above, pp. 306-12. 


\section{Anthrax in South Africa, c. 1910-1945}

accurate picture of the incidence of the disease there. The regulations, which had been in force in the Transkei since 1910, entailed a strong element of social control, limiting the free movement of cattle and enforcing regular insecticidal dipping. ${ }^{93}$ In 1929, du Toit and his colleagues at Onderstepoort, now formally directing field services, initiated a policy of "intensive control", which required stock inspectors to take a regular two-weekly census of cattle in proclaimed areas, while blood smears for diagnostic examination were taken from any cattle that died or were slaughtered. The vets believed that as "intensive control" of East Coast fever would enable them to detect any cases of anthrax that occurred in the Transkei, they would obtain accurate data on the rate and distribution of infection. $^{94}$

In this regard, the vets perceived compulsory vaccination in Engcobo to be an immediate success. Nicol reported that during the year following the introduction of immunization, the number of outbreaks recorded in Engcobo dropped from 61 to 15. Although the government's own statistics showed that anthrax was no more common in the Transkei than in some other major cattle holding areas, the vets targeted it for a pilot anthrax vaccination "campaign". Accordingly, Nicol, in collaboration with the magistrates, extended compulsory vaccination to the rest of the western districts of the Transkei in 1929 and to the whole of the Territories by 1934 . The only exception was the settlerdominated district of Mount Currie, where vaccination remained voluntary. ${ }^{95}$ By 1942 , Nicol announced that his staff were overseeing the annual vaccination of over 1,600,000 cattle in the Transkei-virtually complete coverage. ${ }^{96}$

During the early 1930s, compulsory annual vaccination was extended to other African reserves in various parts of the country. Coverage was less complete than in the Transkei, with "campaigns" targeted at "blocks" of territory thought to be severely affected. Nevertheless, officials conducted these operations on a large scale. In 1933, the Secretaries for Agriculture and Native Affairs, acting on veterinary advice, ordered the annual vaccination of over a quarter of a million head of cattle in five districts in Northern Zululand. ${ }^{97}$ The policy was extended further in Natal, so that by 1937, compulsory vaccination was in force in 101 different African reserves and in locations throughout Natal and Zululand, entailing the treatment of over a million cattle every year. ${ }^{98}$ Compulsory vaccination was intensified in the Griqualand West area, where wholesale vaccination was ordered whenever a case of

\footnotetext{
${ }^{93}$ For an account of popular opposition to the East Coast fever regulations during the 1910 s, see Bundy, op. cit. note 12 above.

${ }^{94} \mathrm{G}$ de Kock, C J van Heerden, R du Toit and W O Neitz, 'Bovine theileriosis in South Africa,with special reference to Theileria mutans', OJVSAI, 1937, 8: 9-128, pp. 9-10; A M Diesel, 'The campaign against East Coast fever in South Africa', OJVSAI, 1948, 23 (1 and 2): 19-31, p. 29.

95 The eleven districts were Elliotdale, Engcobo, Libode, Mqanduli, Ngqeleni, Qumbu, St Marks, Tsolo, Tsomo, Umtata, Xalanga, essentially the western part of the Transkei. Mount Currie was extensively settled by Europeans in the 1870s and remained largely in white hands. Nicol, op. cit., note 2 above, p. 47; Sterne, et al., op. cit., note 1 above, p. 54;
}

Beinart, 'The anatomy of a rural scare', op. cit., note 12 above, pp. 49-51.

${ }^{96} \mathrm{Nicol}$, op. cit., note 2 above, p. 55.

${ }^{97}$ The five districts were Nongoma, Hlabisa, Mahlabatini, Nbombo and Ingwavuma. SABE BAO 5826 2/316 vol. 2, Secretary for Agriculture to Secretary for Native Affairs, 8 June 1933; Secretary for Native Affairs to Chief Native Commissioner, Pietermaritzburg, 26 June 1933.

${ }^{98}$ SABE LBD 4863 Z1002/16 vol. 2, D Edwards, Government Veterinary Officer, Louis Trichardt to Senior Veterinary Officer, Pretoria, 20 Dec. 1935; J L Dixon, Government Veterinary Officer to Senior Veterinary Officer, Pretoria, 15 Nov. 1936; D Edwards, Government Veterinary Officer to Senior Veterinary Officer, Pretoria, 7 Dec. 1936. 


\section{Daniel Gilfoyle}

anthrax was reported in a particular reserve. ${ }^{99}$ Officials initiated similar measures across the Transvaal so that, by the late 1930s, annual compulsory vaccination was in place in fifty-seven African reserves, entailing the treatment of over one-quarter of a million cattle each year. ${ }^{100}$ During 1940, more than 6 million head of cattle, half the total South African population, were vaccinated. ${ }^{101}$ South African officials also encouraged vaccination in neighbouring states by offering to export vaccine to Swaziland, Basutoland (Lesotho), South West Africa and Bechuanaland (Botswana) at the price of five shillings per hundred doses, substantially below the estimated cost of production. ${ }^{102}$

\section{Experimenting with Anthrax: Max Sterne, the Invention of an "Avirulent" Vaccine and the Experimental Function of Mass Vaccination}

If vaccination was in force extensively with an apparent degree of success in South Africa by the 1930s, the practice was not without problems of safety and effectiveness. Difficulties with imported systems of vaccination and associated technology meant that these were subject to critical review by veterinary scientists at Onderstepoort, where an experimental approach to the production and use of vaccine evolved from the mid-1910s through to the 1940s. During the 1930s, the results obtained by mass compulsory vaccination of African-owned cattle came to fulfil an important function in these experiments.

The active constituent of the vaccine first manufactured in South Africa during 1915 was an attenuated strain of the bacillus obtained from the Pasteur Institute in Paris. The key variable determining the safety and efficacy of vaccine was thought to be the degree to which the pathogenic property of the bacilli was reduced through attenuation, achieved by heating according to Pasteur's method. ${ }^{103}$ In terms of contemporary theory, the bacilli needed to be attenuated to a point at which they could no longer cause disease, but were still capable of conferring immunity by stimulating the production of antibodies within the body. The question of attenuation was complicated by variability in the susceptibility of different species of domestic animals. Vets believed, for example, that horses and angora goats were more susceptible than cattle and sheep, so their safe immunization required a more attenuated vaccine. In practice, Pasteurian vaccination consisted of two injections, carried out approximately fourteen days apart. The first used highly attenuated organisms to stimulate an initial immune response, while the second contained less attenuated organisms, which produced immunity sufficient to prevent natural infection.

\footnotetext{
${ }^{99}$ For Vryburg, SABE BAO 5826 2/316 vol. 2, Secretary for Native Affairs to Secretary for Finance, 15 Dec. 1930; for Kuruman, Secretary for Native Affairs to Native Commissioner, Kuruman, 19 May 1931, and Senior Veterinary Officer, OFS to Director of Veterinary Services, 23 Dec. 1931; for Mafeking, Native Commissioner, Mafeking, to Secretary for Native Affairs, 10 Dec. 1932; for Barkly West, Superintendent of Locations to the Native Commissioner, 13 March 1933; for Herbert, Superintendent of Natives to Native Commissioner, Herbert, 26 April 1933.
}

\footnotetext{
${ }^{100}$ SABE LBD 4863 Z1002/16 vol. 2, Memo, 'Native areas in Transvaal, which are subject to annual anthrax inoculations', undated, 1937.

${ }^{101}$ Sterne, et al., op. cit., note 1 above, p. 53.

${ }^{102}$ SABE LBD 4863 Z1002/16 vol. 2, Director of Veterinary Services to Secretary for Agriculture and Forestry, 21 Nov. 1936; Secretary for Agriculture and Forestry, Pretoria, to Secretary for Agriculture and Forestry, Maseru, 29 Jan. 1935.

${ }^{103}$ For a detailed account of Pasteur's methods, see Geison, op. cit., note 15 above, pp. 151-69, esp. pp. $156,167$.
} 


\section{Anthrax in South Africa, c. 1910-1945}

Scientists considered that this protection lasted for little more that a year, so they recommended annual vaccination as a means of maintaining continuous immunity. ${ }^{104}$

Both vets and farmers criticized the Pasteur vaccine as its use expanded in South Africa through the 1910s. As Jan Todd has argued for Australia, Pasteur's system of double vaccination was cumbersome under the conditions of extensive farming which similarly characterized South Africa. ${ }^{105}$ Government vets also complained that the administration of the vaccine, which required the marshalling of cattle on two separate occasions, was particularly difficult among African-owned livestock on communally held land. ${ }^{106}$ For this reason, Kehoe initially concentrated on producing a single version of the vaccine, but he found it difficult to strike a balance between safety and efficacy. The single vaccine sometimes produced crippling swellings and even fatal disease in the animals (particularly the more susceptible horse and angora goat) that it was supposed to protect. From March 1917, therefore, Theiler ordered the cessation of the single vaccine, except for use on cattle when the circumstances made double vaccination impractical. ${ }^{107}$

Apart from safety, stockowners also complained that the vaccine at times failed to confer sufficient protection because animals contracted anthrax during the year following inoculation. Vets noted that vaccination occasionally failed to halt the progress of an outbreak in a herd, suggesting that it did not always produce the required degree of immunity. They considered that the most important reason for this was the poor keeping qualities of Pasteurian vaccines based on the vegetative phase of the bacillus. ${ }^{108}$ In 1922, they began to use a spore-based vaccine along the lines of a product first devised in Australia by the amateur bacteriologists John Gunn and John MacGarvie-Smith during the 1890s. ${ }^{109}$ Their invention was designed to overcome the problem of deterioration during long-term storage and transportation by exploiting the capacity of the bacillus to form resistant spores, thus producing a vaccine which remained viable over long periods. More effective than Pasteur's vaccine under conditions of extensive pastoralism, spore vaccines were in widespread use in America, Australia and Japan by the early 1920s, when they were first produced at Onderstepoort. ${ }^{110}$

Production of a spore vaccine required the selection of a strain of Bacillus anthracis with strong immunizing qualities (different strains were thought to vary greatly in this regard). Samples of strains were obtained from foreign bacteriological institutes or by isolating organisms from local outbreaks. The selected strain of bacillus was attenuated by heating, propagated in a liquid medium and then allowed to sporulate on solid agar in the presence of oxygen. ${ }^{11}$ The scientists used small laboratory animals to test for the appropriate degree of attenuation. The vaccine needed to be strong enough to kill the highly susceptible guinea-pig, but was rejected as insufficiently attenuated if it killed the more resistant rabbit. Tests to determine the efficacy of the vaccine, however, were carried out on

\footnotetext{
${ }^{104}$ Kehoe, op. cit., note 29 above, pp. 232-3, 244.

${ }^{105}$ For an account of anthrax vaccination in Australia, see Todd, op. cit., note 40 above, pp. 46-107.

${ }^{106}$ Archive of the Onderstepoort Veterinary Institute (AOVI), box 65, file 10/5/2, C E Gray, Principal Veterinary Officer, Pretoria, to Director of Veterinary Research, 13 April 1920.
}

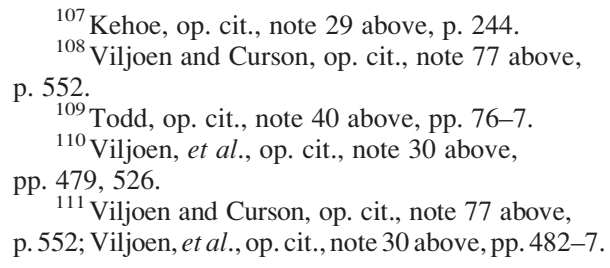




\section{Daniel Gilfoyle}

sheep. Each vaccine dose needed to produce an immunity sufficient to protect the animal from injection with one thousand minimum lethal doses of a standard unattenuated strain. In practice, this meant that the size of the vaccine dose was adjusted until a point was reached at which the challenge no longer killed the test sheep. ${ }^{112}$ The improvements in testing enabled the introduction of a single-dose spore vaccine, of which good results were reported during the $1920 \mathrm{~s}$.

Nevertheless, stockowners and vets in the field continued to report some accidents and failures. As Kehoe had argued during the late 1910s, accidents, while statistically unimportant, had a disproportionate impact on the public perception of vaccination, because they tended to occur in clusters, causing serious hardship to local communities and thus undermining public confidence. ${ }^{113}$ They also suggested to Kehoe and his successor in anthrax research, Philip Viljoen, that existing vaccines were in some way inadequate for satisfactory immunization against anthrax in South Africa. ${ }^{114}$ Since the early 1900s, when Arnold Theiler demonstrated that in certain diseases immunity was specific to local strains of a pathogenic organism, the idea that the immunity produced by infection from one strain did not necessarily protect against others was common currency at Onderstepoort. ${ }^{115}$ The scientists believed that different strains of Bacillus anthracis might vary considerably in their cross immunizing properties. ${ }^{116}$ In this regard, an incident that occurred at Boshoff in the Orange Free State during 1917 was much discussed. Observers described this outbreak, which apparently affected horses only, as unusually severe. Vets used both local vaccine of different batches and vaccine from the Pasteur Institute to immunize horses in the area, but the outbreak continued unabated. ${ }^{117}$ This suggested that there were strains of Bacillus anthracis in South Africa against which the current vaccines were ineffective. A truly efficient vaccine would need to incorporate these local types. As was the case in the United States during the 1920s, scientists at Onderstepoort began to collect and isolate from nature different strains for possible use in a vaccine. ${ }^{118}$

They also continued to evaluate foreign developments in vaccine technology. Imported vaccine, including the Australian McGarvie-Smith vaccine and the American "Sobernheim" system, which used a combination of vaccine and immune serum, were tested and found unsatisfactory under South African conditions. ${ }^{119}$ In 1931, the Instituto Sieroterapico Milanese in Italy began issuing a vaccine under the trade-name "Carbazoo", which contained "saponin", a vegetable glycoside used in the manufacture of soap. This allegedly enabled the use of extremely virulent strains with high immunizing power, which

\footnotetext{
${ }^{112}$ Viloen, et al., op. cit., note 30 above, pp. 486-7.

${ }^{113}$ Kehoe, op. cit., note 29 above, p. 234.

${ }^{114}$ Viljoen, et al., op. cit., note 30 above, pp. 478-9.

${ }^{115}$ For a discussion of Theiler's work in this regard, see Gilfoyle, op. cit., note 25 above.

${ }^{116} \mathrm{~J}$ G Bekker, 'The relation of the virulence of attenuated anthrax strains to their immunizing value', Annual report of the Director of Veterinary Services and Animal Industry, $15^{\text {th }}$ report, volume I, October 1929, Pretoria, Government Printer, 1929, p. 183.

${ }^{117}$ Union of South Africa [U.G.5 -1918], Annual report of the Department of Agriculture, 1916-17,
}

Pretoria, Government Printing and Stationery Office, 1918, p. 47.

${ }^{118} \mathrm{R}$ M Swiderski, Anthrax: a history, Jefferson, NC, and London, McFarland, 2004, p. 155; Kehoe, op. cit., note 29 above, p. 252.

${ }^{119}$ AOVI, box 1, file $1 / 1 / 3$, A Theiler to Secretary of Forestry and Agriculture, 11 Nov. 1922; box 65, file 10/5/2, C Gray, Principal Veterinary Officer, to Director of Veterinary Research, 13 April 1920; box 65, file 10/5/2, A Theiler to R Jones, Veterinary Advisor, Siam, 18 March 1926. 


\section{Anthrax in South Africa, c. 1910-1945}

would otherwise have been too dangerous for vaccination. The scientists isolated the strain of Bacillus anthracis used in Carbazoo and evaluated the effect of saponin on local strains, finding that the substance enhanced the production of immunity rather than reducing the virulence of the organism. As a result, from 1936, Onderstepoort issued a saponin-based vaccine. $^{120}$

If there was little opposition to free vaccination, the expansion of the practice during the 1920s and 1930s was nevertheless accompanied by complaints from both white and African stockowners, to which the scientists responded by adjusting the strength of the vaccine. ${ }^{121}$ Following a spate of accidents in 1926, they released a spore vaccine based on a more attenuated strain, but thereafter the number of cases detected increased, suggesting a lack of immunizing power. As a result, Onderstepoort released a stronger vaccine in 1930 only for the cycle to be repeated soon afterwards. ${ }^{122}$ In 1933, Alexander M Diesel, the Senior Veterinary Officer for Natal, reported "alarming mortality," as well as other symptoms such as severe inflammation and swelling at the site of inoculation, among 30,000 African-owned cattle injected with vaccine from a particular batch. Ondersterpoort received similar complaints at this time from the Transvaal and other parts of the country. ${ }^{123}$ These failures provided evidence of continuing difficulties in striking a balance between safety and efficacy in spite of the various improvements in the technology. While officials might argue that such accidents made up only a small percentage of the total number of vaccinations, they were nevertheless enough "to perturb the makers of the vaccine". 124

The improvement of the vaccine in the face of these setbacks was the task of Max Sterne, an Onderstepoort-trained veterinary scientist and bacteriologist appointed in 1934 to manage vaccine production. ${ }^{125}$ Sterne, who shared the belief of his colleagues that the safety of their product was essential for public approval and the ultimate success of vaccination, initiated new lines of research. ${ }^{126}$ His approach to immunization was radically different from earlier methods, which all depended on reducing the virulence of Bacillus anthracis. Instead, Sterne aimed at solving the problem of safety by completely removing

\footnotetext{
${ }^{120}$ M Sterne, E M Robinson and J Nicol, 'The use of saponin spore vaccine for inoculation against anthrax in South Africa.', OJVSAI, 1939, 12 (2): 279-304, p. 299. See also Swiderski, op. cit., note 118 above, p. 155. p. 11 .

${ }^{121}$ Sterne and Robinson, op. cit., note 79 above,

${ }^{122}$ Ibid., pp. 11, 16.

${ }^{123}$ AOVI, box 65 , file 10/5/2, Senior Veterinary Officer, Natal, to Director of Veterinary Services, Pretoria, 11 Oct. 1933; R Clark, Government Veterinary Officer, Ermelo, to Director of Veterinary Services, Onderstepoort, 14 Oct. 1933; SABE LBD 4863 Z1002/16 vol. 2, K Schulz, Government Veterinary Officer, Kimberley, to Director of Veterinary Services, Pretoria, 15 Jan. 1934; SABE BAO 5862 2/316 vol. 2, Native Commissioner, Nongoma, to Native Commissioner, Pietermaritzburg, 31 April 1934 and 2 July 1934.
}

\footnotetext{
${ }^{124}$ BAO 5826 2/316 vol. 2, Secretary for Forestry and Agriculture to Secretary for Native Affairs, 10 April 1934

${ }^{125}$ Max Sterne (1905-1997) was borne in Trieste and, at the age of four, emigrated with his parents to South Africa. He graduated from Onderstepoort veterinary faculty with the degree of Bachelor of Veterinary Science in 1928. Sterne joined the Onderstepoort laboratory in 1934 to supervise the production of anthrax vaccine. His work on variation in Bacillus anthracis was successfully submitted for a doctoral thesis and was published in full in the Onderstepoort Journal. In 1951, he moved to Britain, where he was employed by the Wellcome Research Laboratories. R D Bigalke, 'The fourteen editors of the Journal of the South African Veterinary Medical Association', Journal of the South African Veterinary Association, 2000, 71: 68-76.

${ }^{126}$ Sterne and Robinson, op. cit., note 79 above, p. 11 .
} 


\section{Daniel Gilfoyle}

the virulence (capacity to cause disease) of the organism, while retaining its ability to stimulate the production of immunity. Perhaps influenced by the conception of Bacillus anthracis as an environmental actor currently in vogue at Onderstepoort, he was concerned with the biology of the organism, its behaviour under different environmental conditions and the significance of this for immunization.

Sterne described how bacteriologists in Europe and America had linked the virulence of Bacillus anthracis to the ability of the organism to form a "capsule" or cell wall, which enabled it to evade phagocytosis (destruction by certain white blood cells). Bacilli which did not produce capsules were rapidly destroyed by the body's non-specific immune defences and were therefore thought to be avirulent (unable to produce disease). This property of encapsulation was, however, variable. Earlier researchers had found that encapsulation in anthrax cultures could be encouraged or discouraged by manipulating the amount of carbon dioxide present in the atmosphere. The degree of encapsulation was judged by the appearance of a culture to the naked eye. Virulent strains cultured in normal air were unencapsulated and colonies grown on solid media appeared "rough" on the surface and edges. The same strains grown in a higher concentration of carbon dioxide (similar to that within the animal body) developed capsules. As the percentage of capsuled organisms increased, the colony took on a smoother, "mucoid" appearance to the naked eye. ${ }^{127}$

Sterne thought that previous researchers had missed the potential significance of this variation for immunization. ${ }^{128}$ In the course of propagating a series of these smooth variants in a high percentage of carbon dioxide, he noticed that some of the colonies began to display rough, unencapsulated outgrowths. When these unencapsulated organisms were cultured in ordinary air they remained rough, and when transferred back to carbon dioxide they failed to revert to the smooth capsulated form. It seemed that these "dissociated" variants had permanently lost their ability to form capsules, even, perhaps, in the carbon dioxide rich environment of the animal body. Sterne reasoned that as the property of encapsulation was associated with virulence, it was likely that these stable rough variants were avirulent. This apparently proved to be the case; they failed to produce any symptoms when injected into highly susceptible guinea-pigs. It was therefore sometimes possible to render a virulent strain of Bacillus anthracis avirulent by culturing it under controlled conditions in the laboratory. ${ }^{129}$ Previous authorities on anthrax immunization generally insisted that a degree of virulence in the constituent organisms was necessary for a vaccine to produce immunity. Sterne was aware, however, of German studies from the 1910s, which suggested that apparently avirulent forms of Bacillus anthracis found in nature could sometimes produce immunity. Such proved to be the case; guinea-pigs injected with the unencapsuled, avirulent "disassociants" of certain strains were later able to resist very large doses of a highly virulent strain. ${ }^{130}$

These results raised the possibility of a completely avirulent vaccine, which Sterne hoped would solve the problem of safety. A major practical problem was that the initial

\footnotetext{
${ }^{127} \mathrm{M}$ Sterne, 'Variation in Bacillus anthracis', OJVSAI, 1937, 8: 271-350, p. 272. Sterne quoted a number of articles published in Europe and America in describing these phenomena.
}

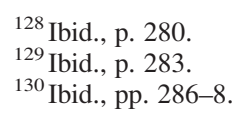




\section{Anthrax in South Africa, c. 1910-1945}

production of the smooth variants from the rough, virulent organisms obtained from nature was a long, tedious and unreliable process, which made it difficult to evaluate the immunizing properties of many strains. A method of producing encapsulated smooth growths regularly was required. Sterne theorized that the characteristic roughness of strains obtained from dead animals might be an adaptation to the "normal" atmosphere under which they were cultured in the laboratory. The conditions under which Bacillus anthracis usually multiplied, however, were those of the blood-stream of a living animal. It might be that the roughness which characterized these cultures was a biological adaptation to the "hostile" physical environment in which they had been grown. Capsuled smooth cultures might be obtained more easily under conditions which emulated the natural environment for the propagation of the organism, the animal body. ${ }^{131}$

Sterne knew from the literature that anthrax bacilli formed capsules when cultured in blood serum, but fluid media were useless for studying the morphology of colonies and "picking" variants, as the organisms diffused and intermingled in the liquid. ${ }^{132}$ Further progress depended on a local technical innovation. Sterne's colleague, the British bacteriologist J H Mason, devised a tube containing a semi-solid medium of horse serum and agar in which the concentration of carbon dioxide could be manipulated. ${ }^{133}$ Using this invention, Sterne found he could easily grow encapsuled smooth variants which regularly threw out growths of rough unencapsuled bacilli. These unencapsulated dissociants all turned out to be avirulent when injected into guinea-pigs and some seemed to give a good degree of protection against the injection of virulent cultures. ${ }^{134}$

The remainder of Sterne's work on anthrax was a process of evaluating the immunizing properties of different strains, working out the optimal doses of "avirulent" "135 vaccine for different species of domestic animals with varying degrees of susceptibility and devising a means of mass-producing the vaccine. ${ }^{136}$ He eventually chose an unencapsuled dissociant of a strain designated 34F2, which had been isolated from a severe outbreak. ${ }^{137}$ Production of the vaccine was technically a simple matter. Bacilli were picked from the dissociant colony, allowed to sporulate and then freeze-dried. When vaccine was required, the manufacturers germinated the spores and propagated them in large quantities on solid agar. These cultures were then allowed to sporulate in oxygen (to ensure the keeping property of the vaccine) and washed off into saline at a standard concentration for division into metred individual doses. The avirulent nature of the new vaccine was significant for quality control. As it now immunized, rather than killed guinea-pigs, they could be used for

\footnotetext{
${ }^{131}$ Ibid., p. 310; J H Mason, 'A new culture tube', JSAVMA, 1933, 4: 89-90.

${ }^{132}$ For the importance of Robert Koch's invention of solid media to the study of bacterial morphology and colonies, see Mazumdar, Species and specificity, op. cit., note 15 above, p. 76 .

${ }^{133}$ Mason, op. cit., note 131 above, pp. 89-90.

${ }^{134}$ Sterne, op. cit., note 127 above, pp. 309-36.

${ }^{135}$ According to present knowledge, the virulence of Bacillus anthracis depends on its ability to produce toxin and capsules, which are independent genetic characteristics, designated PXO1 (toxin) and PX02 (capsule). Sterne's “avirulent" strain lacked the PX02, but retained PX01, so was therefore not truly avirulent.
}

Stern acknowledged that the vaccine could produce inflammation in horses and goats and issued a separate vaccine for them. Swiderski, op. cit., note 118 above, p. 161.

${ }^{136} \mathrm{M}$ Sterne, 'The effects of different carbon dioxide concentrations of the growth of virulent anthrax strains. Pathogenicity and immunity tests on guinea-pigs and sheep with anthrax variants derived from virulent strains', OJVSAI, 1937, 9: 66.

${ }^{137}$ M Sterne, 'The use of anthrax vaccines prepared from avirulent (uncapsulated) variants of Bacillus anthracis', OJVSAI, 1939, 13: 307-12, p. 307. 


\section{Daniel Gilfoyle}

testing the degree of immunity produced by the vaccine. Furthermore, the results obtained with the guinea-pig proved predictive for large animals, so there was no longer the need for expensive large-scale testing on sheep. Sterne believed that safety was not at issue so there was no formal testing, although individual batches of vaccine were initially injected into a small number of animals in the field to check that they produced no severe reactions. Vaccine derived from strain 34F2 was used for all animals, but smaller doses were found necessary for horses and goats. ${ }^{138}$

The "avirulent" vaccine was first released for field trials in 1936 and used on a large scale from 1938. ${ }^{139}$ Initially, however, Sterne for two reasons advised a certain caution in advancing the merits of his invention. First, he believed that the results obtained in laboratory experiments were unreliable guides to the outcome of field vaccination, where quite different environmental conditions pertained. ${ }^{140}$ Second, he considered it difficult to control field vaccination sufficiently, "to produce statistically sound evidence of a vaccine's efficacy in the field". ${ }^{141}$ An experimental system of sufficient "statistical soundness" to prove the safety and efficacy of the vaccine, however, already existed in the Transkei.

Large-scale compulsory vaccination in the Transkei, where vets and other officials had closely monitored mortality in cattle since the late 1920s, provided a means of obtaining the statistical data that Sterne desired for the evaluation of the vaccine. Furthermore, because the enforcement of hygienic measures against anthrax in the Transkei had been abandoned as impractical, the scientists took the effectiveness of the vaccine as the sole variable in determining the incidence of the disease. ${ }^{142}$ As all cattle in the Transkei were vaccinated annually, and the vets were confident that they could detect virtually all new cases, the conditions were sufficiently controlled for the manipulation of vaccination to have the status of "an extensive experiment". ${ }^{143}$ In this regard, the inverse relation between the degree of attenuation of the earlier vaccines and the annual incidence of cases revealed by inspection had been very striking. The number of reported outbreaks fell from 433 in 1928 to 34 in 1932 (following the instigation of comprehensive vaccination), but rose again to 143 by 1936 after the release of a more attenuated vaccine. Sterne took this as conclusive evidence that the further attenuation of the strain of Bacillus anthracis in use had resulted in an appreciable decline in the efficacy of the vaccine. ${ }^{144}$

If mass vaccination in the Transkei demonstrated conclusively the contradiction between safety and efficacy in the use of vaccines based on virulent strains, Sterne and his colleagues now used the Transkei for what was, in effect, a large-scale clinical trial of the "avirulent" vaccine. During 1938, Nicol used the new product to treat 271,500 head of cattle in the Transkei district of Butterworth. The vaccine produced no injuries and

\footnotetext{
${ }^{138}$ In practice six guinea-pigs were injected with $0.01 \mathrm{cc}$ and another six with $0.001 \mathrm{cc}$ of the spore suspension (vaccine). A batch of vaccine was passed only if all the guinea-pigs which had received $0.01 \mathrm{cc}$ of vaccine survived an injection containing a standard dose of a virulent strain of anthrax. Typically, only some of the six which received $0.001 \mathrm{cc}$ survived the test. A field test was also carried out on sheep using an injection which contained four times the concentration of spores used in the standard vaccine. This was to
}

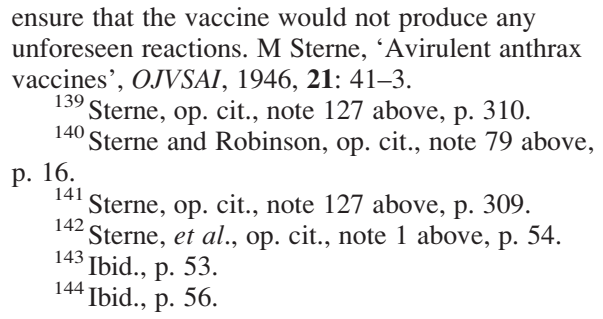




\section{Anthrax in South Africa, c. 1910-1945}

in the following year only five cases of anthrax were recorded in the district (calculated as 0.0018 per cent of the population), slightly better than the results obtained with spore and saponin-spore vaccines in the surrounding districts. Thereafter, the new vaccine was used throughout the Transkei. By 1941, the number of outbreaks of anthrax reported in the Transkei had fallen from 433 in 1928 to a new low of 17. For the rest of South Africa excluding Natal (where compulsory vaccination had been imposed on a large scale, if not comprehensively), the corresponding figures were 500 and 262. The real number was probably much greater, as the vets estimated that they were probably able to detect only one in seven outbreaks outside the Transkei, in areas where they were unable to exercise a similar degree of control through the operation of the East Coast fever regulations. The argument that the Transkei was a reservoir of infection was reversed and the Transkeian administration now required the vaccination of cattle entering the Territories from the rest of South Africa. ${ }^{145}$ The adjoining district of Mount Currie, populated by "progressive and prosperous Europeans", was more heavily infected than the African-occupied Transkei. ${ }^{146}$

The results recorded in the Transkei were sufficient to allay Sterne's own concerns that mass vaccination in the field might contradict the successful laboratory experiments of the mid-1930s. They provided convincing statistical evidence supporting the efficacy of vaccination. ${ }^{147}$ During the early 1940 s, the veterinary controversy about the efficacy of vaccination against anthrax closed. The "experiment" in the Transkei powerfully supported arguments in favour of compulsory annual immunization using "avirulent" vaccine. Anthrax was apparently close to eradication in the Transkei, an area in which state vets and officials had historically found it very difficult to control animal diseases. On the other hand, hygienic measures combined with voluntary vaccination seemed to have been less effective on farms owned by whites. There was also closure of the scientific debate about the safety of vaccination. Once Sterne's "avirulent" vaccine had been adjusted for species of differing susceptibility, it was regarded as harmless. In future, Onderstepoort scientists blamed accidents with vaccination exclusively on operator error or other extraneous factors.

During the mid-1940s, now that veterinary policy makers had sufficient confidence in Sterne's invention, the state extended compulsory block vaccination to white farms in the Mafeking district of the Northern Cape and the Witwatersrand, as well as many other Transvaal districts. ${ }^{148}$ In 1947, the senior government vet, Alexander Diesel, considered the fact that officials in South Africa were still unable to guarantee that exported animal hides were uncontaminated. While continuing to stress the need for hygienic measures, Diesel wrote that, "For some months now, this Division has been arranging block inoculation of all cattle in the more severe anthrax areas of the Union. This method of control will be extended as far as possible as it is felt to be the only solution in the control of anthrax." 149

\footnotetext{
${ }^{145}$ SABE BAO 5826 2/316 vol. 2, Secretary for Forestry and Agriculture to Secretary for Native Affairs, 3 Oct. 1933.

${ }^{146}$ Sterne, et al., op cit., note 1 above, p. 61.

${ }^{147}$ Sterne and Robinson, op. cit., note 79 above, p. 16; M Sterne, 'The use of anthrax vaccines prepared from avirulent (unencapsulated) variants of bacillus anthracis', OJVSAI, 1939, 13 (2): 309.

${ }^{148}$ Union of South Africa, Government Notice No. 2699-20 Dec. 1946. The complete list was Benoni,
}

Bethal, Boksburg, Brakpan, Bronkhorstspruit, Germiston, Groblersdal, Johannesburg, Krugersdorp, Lydenburg, Marico, Nigel, Pietersburg, Potgietersrus, Pretoria, Roodepoort, Rustenburg, Springs, Standerton, Vereeniging, Witbank and Zoutpansberg. ${ }^{149}$ SABE LBD Z1023 vol. 2, A M Diesel, for Director of Veterinary Services to Secretary for Agriculture and Forestry, 28 Oct. 1947. 


\section{Daniel Gilfoyle}

Sterne's invention, the "avirulent" spore vaccine based on the unencapsuled strain $34 \mathrm{~F} 2$, spread throughout the world during the 1940s and replaced other forms of vaccination. It remains the standard method of animal vaccination against anthrax to the present and provided the basis for subsequent research into a human vaccine. ${ }^{150}$ The vaccine contributed to the rising reputation of the Onderstepoort Veterinary Institute in the international technoscientific network and followed the publication of a number of important research findings on vaccines, toxicology and animal nutrition. The cattle owners of the Transkei, placed under the veterinary regime entailed by the East Coast fever regulations, unknowingly provided the testing ground for a vaccine technology which subsequently achieved worldwide currency.

\section{Conclusion}

State veterinary medicine in South Africa has been described in the historiography as a means of fostering commercial production by white South African pastoralists, but during the 1920s and 1930s, Africans were the major recipients of anthrax vaccine. During the first twenty years of the twentieth century, veterinary officials in South Africa believed that anthrax infection was becoming increasingly widespread and serious throughout much of the country. By the early 1920s, the perceived prevalence of anthrax in South Africa meant that the country faced the possibility of sanctions against some of its pastoral products. In order to overcome this threat, the South African government instigated an increasingly intensive campaign to control and reduce the incidence of the disease in the country. While government vets stressed the need for hygienic measures based on the efficient reporting and detection of individual outbreaks, they believed that a lack of resources, combined with public unwillingness to co-operate, doomed these measures to failure. They identified the incidence of anthrax among African-owned stock as presenting particular problems for a policy based solely on notification and hygiene. Vaccination therefore became a key element of the state's disease control strategy.

From the 1920s, the South African state both encouraged and enforced vaccination against anthrax on a large scale. During the 1920s and 1930s, however, the vets encountered considerable technical problems with vaccination, which led to a programme of research at the Onderstepoort Veterinary Institute. In spite of these difficulties and in the context of a segregated society, the vets commenced the mass compulsory vaccination of cattle in various African reserves and locations towards the end of the 1920s, particularly in the Transkei. Veterinary policy makers believed that the existing disease reporting regulations gave them an accurate picture of the incidence of anthrax there and used the statistics to judge the efficacy and safety of different types of vaccine. Later, the compulsory immunization of cattle in the Transkei functioned as an extensive clinical trial for Sterne's "avirulent" vaccine. In this regard, the vaccination of African-owned cattle underpinned the use of new vaccine technology across South Africa and eventually in other parts of the world. It thus contributed to the increasing prestige of the Onderstepoort Veterinary Institute in the international technoscientific network.

\footnotetext{
${ }^{150}$ Swiderski, op. cit., note 118 above, pp. $156-8$.
} 